\title{
Reasons for the Current Afghan Migration to the EU
}

Qualitative research on the reasons for and against migrating to the EU in

North and North-East Afghanistan

\author{
Hayatullah Jawad (AHRRAO) \\ Jan Koehler (ARC) \\ Kristóf Gosztonyi (ARC)
}

A report to the Germany Foreign Office by:

Afghan Human Rights Research and Advocacy Organisation (AHRRAO),

Mazar-e Sharif, Afghanistan

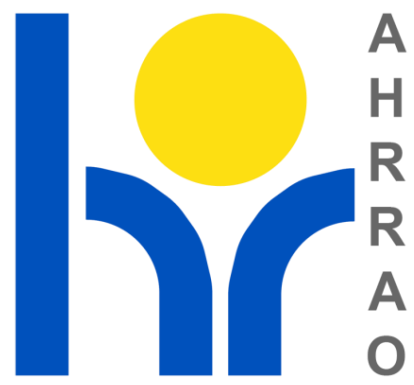

In cooperation with:

ARC GbR Koehler \& Gosztonyi, Berlin, Germany

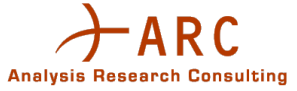




\section{About the Afghan Human Rights Research and Advocacy Organisation (AHRRAO)}

AHRRAO is an independent research and advocacy organisation based in Mazar-e Sharif, Afghanistan. Its mission is to increase understanding and respect for human rights and the rule of law through the dissemination of information, to influence public policy and practices by conducting high-quality, policy-relevant research, to promote a culture of research, learning and actively advocating for the implementation of its recommendations in accordance with laws and legislations. To achieve its mission AHRRAO engages with governmental institutions, civil society, researchers and university students to promote their knowledge, strengthen their research capacity and create opportunities for analysis, reflection and debate.

AHRRAO was founded by Hayatullah Jawad in 2010 and has a board of directors that includes university lecturers, representatives of non-governmental organizations and journalists. AHRRAO currently participates in projects of the United States Institute of Peace (USIP), the Deutsche Gesellschaft für Internationale Zusammenarbeit (GIZ) and the Free University of Berlin. 


\section{Acknowledgements}

The project was managed and implemented by the Afghan Human Rights Research and Advocacy Organisation (AHRRAO). AHRRAO would like to say thank you to all those who participated in the research. The fieldwork was carried out by a team of seven AHRRAO researchers. Anastasia Koehler (Free University Berlin) coded the interviews in NVIVO, Dr. Kristóf Gosztonyi and Dr. Jan Koehler (both ARC) wrote the report with important inputs from Fahim Hakim who also provided important support during project implementation. AHRRAO would also like to express its gratitude to Provincial Economic Departments and Provincial Departments of Refugees and Repatriation of Balkh, Jawzjan, Baghlan and Takhar provinces for their kind support of project fieldwork, active participation in project conferences and sharing their information and arguments. 


\section{Table of contents}

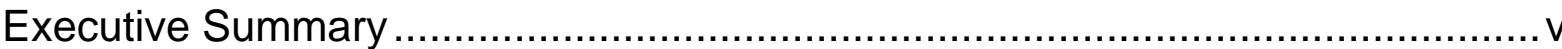

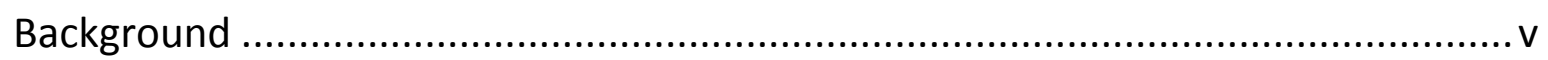

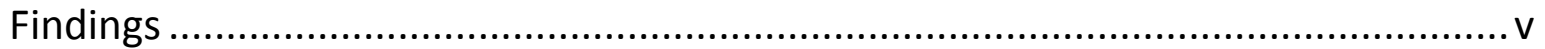

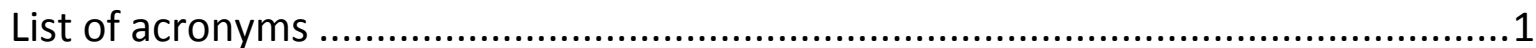

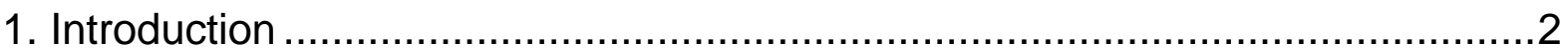

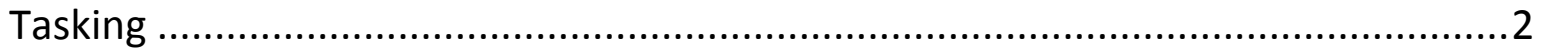

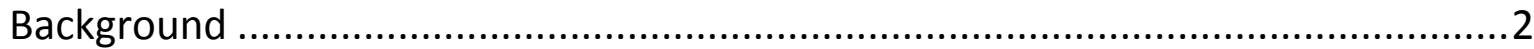

Research questions to be investigated..........................................................

Research methodology and implementation ...............................................

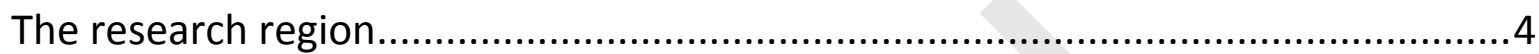

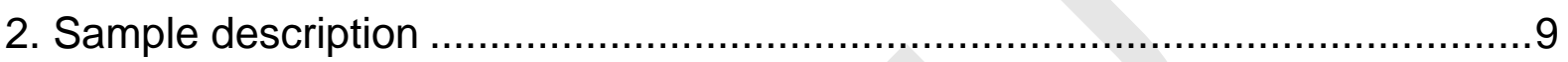

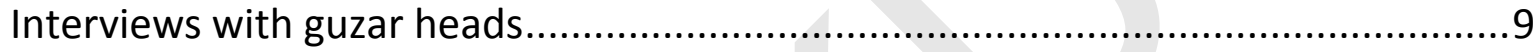

Interviews with household representatives ................................................

Interviews with government representatives ...........................................12

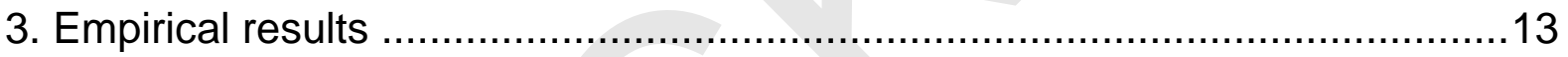

General perceptions, migration frequency and migration patterns....................13

City, guzar and household characteristics and migration frequency.....................16

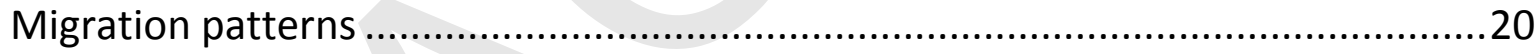

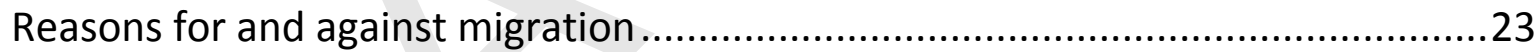

Attitudes of the Afghan Government.......................................................... 30

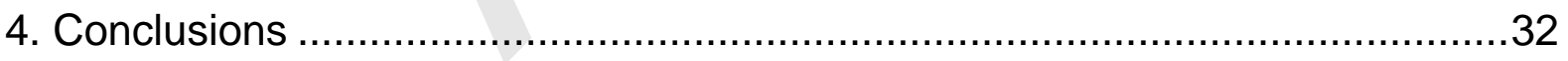

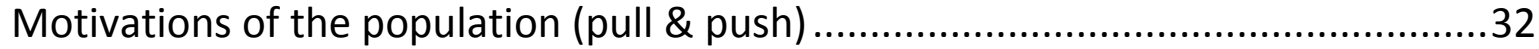

Smuggler fees and modes of migration...................................................... 33 


\section{Executive Summary}

\section{Background}

During the course of 2015, the number of migrants arriving in Europe more than doubled in comparison to the previous year. Of those making the journey, Afghans represent the third largest migrant group (14\% of registered asylum seekers in the EU), with many choosing Germany as their final destination. This report discusses the causes of this large-scale migration, dividing its drivers into 'push and pull factors', and also outlining inhibiting factors. The report is based on field research carried out in four Northern and North-Eastern Afghan cities (Sheberghan, Mazar-e Sharif, Pul-i Khumri and Taloqan). The core of the study comprises 195 guideline interviews with households that have migrant members $(61 \%)$ as well as with households that do not have migrant members $(39 \%)$.

\section{Findings}

This qualitative study confirmed that among the push-factors influencing migration from Northern Afghanistan, insecurity (mentioned in 155 interviews) and economic problems (mentioned in 149 interviews) were predominant. Interviewees widely referenced general insecurity, indicating a lack of trust in the state to effectively manage law and order, and contain insurgency. They mentioned specific, concrete threats less frequently (there were seven cases relating to threats to migrant household members). Economic problems adduced as a push factor predominantly related to unemployment, poverty and the expectation of further hardship. Notably, interviewees did not mention discrimination and oppression on religious or ethnic grounds by the state to any significant extent.

Most powerful among the pull factors adduced was the perception of a welcoming culture for refugees (mentioned in 145 interviews), particularly in Germany, the economic pull of anticipated job opportunities across the EU (mentioned in 79 interviews), and, importantly, a sharp drop in the cost of illegal migration to the EU in 2015 and early 2016 (mentioned in 134 interviews). Interviewees also frequently mentioned the role of positive information about the possibility and prospects of migration, as well as peace and security prevailing in European countries (mentioned in 89 interviews).

Only a small number of "inhibiting factors", discouraging migration, mitigated these significant push-and-pull factors. Most important among these was the risk of rejection of asylum claims (mentioned in 152 interviews, but many respondents believed this risk is intentionally exaggerated by the media); a sense of patriotism understood as a need to develop and defend the homeland (mentioned in 109 interviews); and insufficient funds to migrate (mentioned in 79 interviews, despite the sharp drop in the cost of illegal migration). Interviewees knew about the risks of the journey, but this was generally not considered a strong inhibiting factor. 
These drivers of migration (the push, pull and inhibiting factors) as extracted from 195 guideline interviews conducted in early 2016, explain the growing readiness to leave Afghanistan and to choose Europe (and Germany in particular) as the preferred destination. However, the study found that worsening security and economic prospects, on the one hand, and the stability and welcoming attitude towards migrants in Europe on the other, could not fully explain the dramatic increase in migration beginning in early 2015 , and dropping sharply in spring 2016 after the EU-Turkey migrant deal came into effect. In fact, significant downturns in security and the economy had occurred on occasions before 2015, and the notable perception of a strong "welcoming culture" for migrants in Germany only emerged in the media in autumn 2015.

Therefore, the study strongly points to one specific and overlooked driver explaining the significant change in migration dynamics between late 2014 and early 2016, namely a dramatic drop in the financial cost of migration starting in late 2014 , and prevailing until early 2016 . The cost of migration during this period decreased by approximately $85 \%$, compared to average costs in previous years (from approximately $\$ 14-17,000$ until late 2014 to $\$ 2,500-3,000$ in 2015 and early 2016). Therefore, in 2015 people stated that they felt able to undertake large parts of the journey independently - without the help of smugglers - saving significant amounts of money that would have been previously paid to people smugglers. The shift from "smuggler-facilitated" to mostly "self-organised" illegal migration coincided with a more permissive attitude by authorities in key transit states - most importantly Turkey - in terms of formal and informal administrative and law-enforcement harassment of migrants. The EU-Turkey migrant deal in force since 20 March 2016 seems to have re-established the status quo ante. Since then the costs of illegal migration have significantly risen again (prices are back to approximately $75 \%$ of their 2014 levels) and professional smugglers are back in business facilitating illegal migration from Afghanistan to the EU. 


\section{List of acronyms}

AHRRAO Afghan Human Rights Research and Advocacy Organisation

AlHRC Afghanistan Independent Human Rights Commission

ARC Analysis Research Consulting

ANP Afghan National Police

ANA Afghan National Army

ANSF

Afghan National Security Forces

AOG Armed Opposition Group

CSOs Civil Society Organisations

DoE Department of Education

DoEc Department of Economy

DoLSA Department of Labour and Social Affairs

DRR Department of Refugees and Repatriation

DoWA Department of Women's Affairs

EU European Union

GoA Government of Afghanistan

$\mathrm{HH} \quad$ Household

IO International Organizations

IOM International Organisation for Migration

ICD Information and Culture Department

ISAF International Security Assistance Forces

MoFA Ministry of Finance Affairs

NGOs None-Governmental Organisations

NUG National Unity Government

PC Provincial Council

UN United Nations

UNHCR United Nations High Commissioner for Refugees 


\section{Introduction}

\section{Tasking}

The Afghan Human Rights Research and Advocacy Organisation (AHRRAO) was tasked by the German Foreign Office with conducting research on the reasons for migration and flight from Northern Afghanistan to the EU and Germany. The main research questions to be answered by the investigation have been identified as follows:

- What are the main motives for Afghans to illegally migrate?

- What are the main factors inhibiting Afghans from illegally migrating to the EU?

- Does trust in the Afghan Government play a role in the migration decision?

- How does the Afghan Government relate to the question of illegal migration to the EU?

The investigation was to focus on urban areas, as it was believed that the most migrants came from such backgrounds.

\section{Background}

After years of relatively low rates of asylum seekers entering the EU in the 2000s (2300,000 asylum seekers per year), the number of asylum applications gradually began to rise towards the end of the first decade of the millennium. However, the numbers reaching Europe literally exploded in the course of 2015, rising from about 600,000 to more than 1.28 million. ${ }^{1}$ Germany, the country receiving the largest number of refugees, registered 441,800 asylum claims in $2015 .^{2}$ The actual number of refugees reaching Germany was, however, significantly higher, with an estimated total of 1.1 million refugees. ${ }^{3}$ The refugee wave led to severe tensions between and within EU member states.

The reasons for the sudden dramatic growth in numbers of refugees and migrants are clearly linked to the ongoing civil war in Syria and Iraq (with $29 \%$ Syrians are the first and with $10 \%$ Iraqis the third largest group of refugees) as well as to the deteriorating security situation in Afghanistan (with 14\% Afghans represent the second largest group ${ }^{4}$ ). However, precisely how this link works and why this dramatic

\footnotetext{
${ }^{1}$ http://ec.europa.eu/eurostat

$2 \frac{\mathrm{http}: / / \text { ec.europa.eu/eurostat }}{\text { htp://www.wet.de/poitik/deu }}$

${ }^{3}$ http://www.welt.de/politik/deutschland/article150678614

The difference between the number of asylum requests filed in Germany and the actual number of refugees / migrants entering the country is due to delays in filing an asylum request, which can take several months following arrival in the country.

${ }^{4}$ Approx. 176,000 first time asylum applicants.
} 
spike in refugees entering the EU occurred in 2015 is unclear. After all, the Syrian civil war has been raging since 2011, and the situation in Afghanistan, while deteriorating, has not even closely reached the intensity of the Syrian civil war. The assignment of the German Foreign Office to AHRRAO to investigate why so many Afghans migrated to the EU in 2015 thus aims to shed light on a very important component of the ongoing refugee crisis.

\section{Research questions to be investigated}

Based on the existing literature on migration, and the debate on the reasons for the current wave of Afghan migrants entering the EU and Germany, we defined six possible explanations for the sudden increase in migrant numbers. We reformulated these suggestions as research questions:

- What is the role of unemployment and the generally poor economic situation in motivating people to leave the country?

- What is the role of insecurity (insurgency, political squabbling, and international troop withdrawal) in motivating people to leave the country?

- What is the role of bad governance, the perceived inefficiencies of Afghan Government and the resulting lack of trust in the government in motivating people to leave the country?

- What is the role of human smugglers and changes in the cost of illegal migration in motivating people to leave the country?

- What is the role of the generally high living standards in the EU in motivating people to leave the country?

- What is the role of Germany's "welcome culture" in motivating people to leave the country?

Subsequently we designed the survey questionnaires to provide answers to these questions.

\section{Research methodology and implementation}

In order to answer these research questions, AHRRAO proposed a qualitative investigation using guideline interviews and focus group discussions. Work started with a desktop study identifying main assumptions related to migration in general and the recent migration of Afghans in particular. This was followed by the development of the survey methodology including the interview forms and the sampling approach. The draft interview guidelines and research tools were tested in Mazar-e Sharif between 30 and 31 of January 2016. Survey staff, consisting of six colleagues and one volunteer, mostly AHRRAO associates participating in previous 
studies, were then trained in Mazar-e Sharif on 1 and 2 February. A renewed test run was held in Mazar-e Sharif on 3 February. After adjustments made to the research tools, the actual fieldwork started on 4 February and ended on 5 March (still prior to the key date of 20 March when the Turkey-EU migrant deal came into effect). The fieldwork was continuously monitored and supervised by Hayatullah Jawad, the Project Principle Investigator. The fieldwork faced no serious obstacles, except with regard to coordination with certain governmental organizations - in particular coordination and project facilitation in Jowzjan proved difficult with some officials initially requesting bribes for supporting project in the province.

The translation of the interviews, profile transcripts and data cleaning started on 20 February and was done parallel to the fieldwork. Interview transcripts were fully translated by 15 April after which time Anastasia Koehler entered the English translations into NVIVO, a qualitative data analysis software. By 4 May 2016 the data input into NVIVO and basic coding were completed and the team could begin with the actual analysis and report writing. The report was written and compiled by a team comprising of Jan Koehler (ARC), Kristóf Gosztonyi (ARC) and Hayatullah Jawad (AHRRAO). The actual analysis and report writing lasted from 5 to 18 May 2016 (first draft).

\section{The research region}

\section{Main developments in Afghanistan since 2014}

After years of rapid urbanisation and economic growth in the cities including employment with foreign organisations and work in foreign funded projects, Afghan cities experienced a sharp decline in their fortunes in recent years. Though reliable statistics are missing, unemployment and underemployment appear to have increased dramatically since 2014 when ISAF's withdrawal entered its last stage.

In addition to poverty and the worsening economy, the security situation also deteriorated in the course of 2015. The end of 2014 marked the final withdrawal of ISAF and the transition of the foreign military presence to Resolute Support, a mission that was only supposed to train and further build up the Afghan National Security Forces (ANSF) and not to engage in active combat. Concurrent with the transition of the international military mission, security deteriorated dramatically in the course of 2015 culminating in the temporary fall of the key northern city of Kunduz in late September 2015. Even though the city was rapidly retaken by government forces supported by international military, the fall of the city sent shockwaves through the North and North-East. 


\section{North and North-East Afghanistan}

Turning to the narrower research region, the four provinces of the survey form part of two Afghan regions: the North (Jowzjan and Balkh) and the North-East (Baghlan and Takhar). The two regions share several common features and in many respects form an interlinked cultural, political and ethnic entity. Contrary to the Southern and Eastern Afghanistan, the North and North-East are ethnically and linguistically mixed consisting of Tajiks, Uzbeks, Pashtuns, Hazaras, Turkmens, as well as several other smaller groups. Lacking a census, the precise proportion of these different ethnic groups is unclear. The ethnic mixture of the region as a whole is also reflected in the population of the surveyed cities, which are all multi-ethnic.

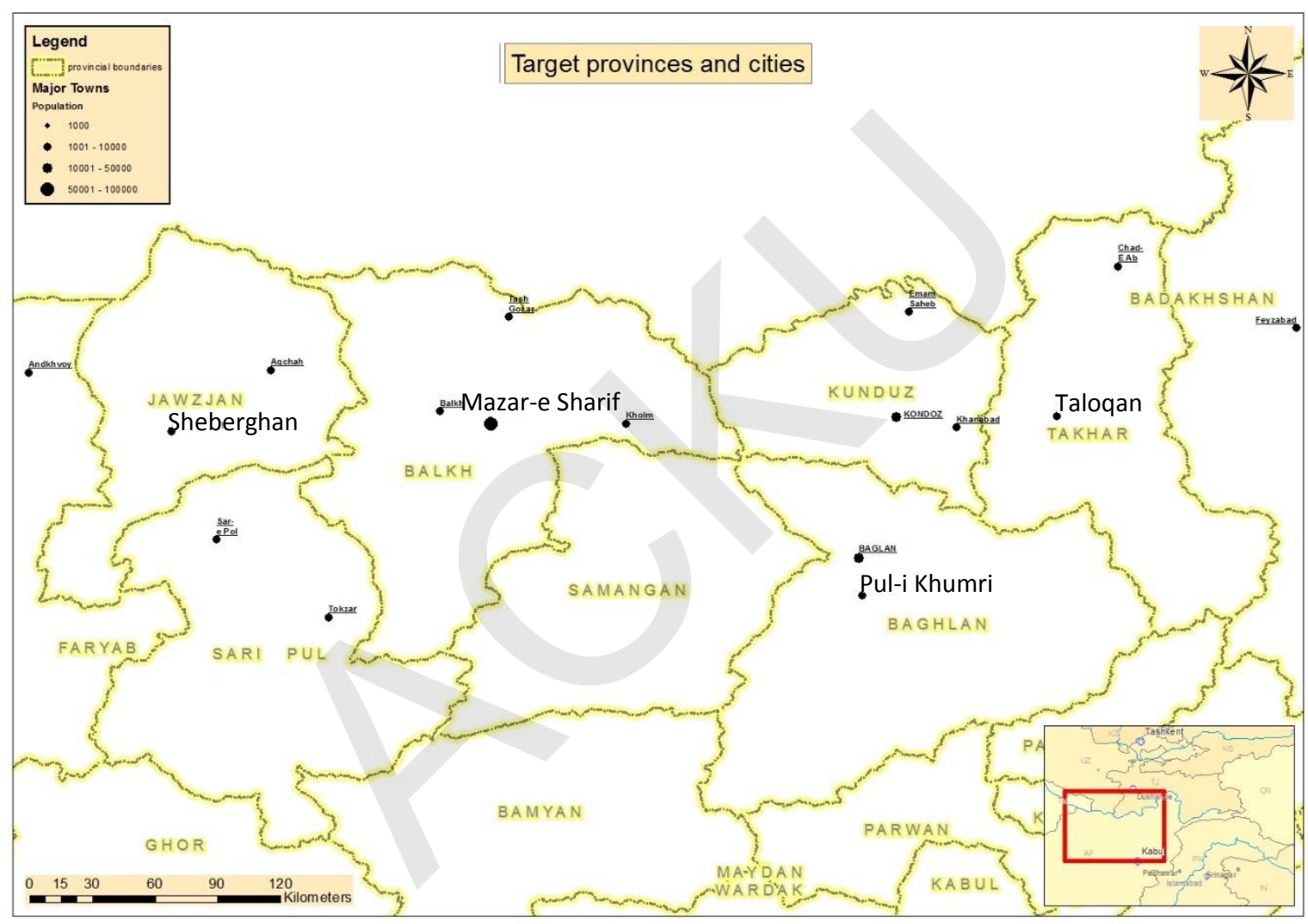

Map 1: The four survey cities 
With regard to the insurgency, the region is far from the Pashtun homeland of the Taliban in Kandahar and, historically at least, showed no great sympathy for the Taliban insurgency. On the contrary, the diverse ethnics groups of the region were associated with the anti-Taliban Northern Alliance. The Taliban takeover of most of the North and North-East in the late 1990s was perceived as traumatic by nonPashtun ethnic groups of the region. The only exception, the Pashtuns, have a somewhat more ambiguous attitude towards the Taliban. As a result of this widespread anti-Taliban sentiment, the insurgency was relatively slow to gain a foothold in the North and North-East. Nonetheless, by mid- to late 2009, the insurgents were present and active in most provinces and in some areas even managed to overcome the Pashtun / non-Pashtun ethnic divide. In particular Uzbeks and Turkmen proved somewhat more open to ally themselves with the insurgency.

At the time of the survey in early 2015, all survey provinces were to varying degrees affected by insurgency and insecurity. The insurgency was most threatening in Baghlan (a province with a large ethnic Pashtun minority) and Jowzjan (a majority Uzbek province). Balkh (mixed with large Tajik, Uzbek, Hazara and Pashtun minorities) and Takhar (mostly Uzbek and Tajik), remained less effected.

\section{The four survey cities}

The survey was carried out in four Northern and North-East cities: Sheberghan, Mazar-e Sharif, Pul-i Khumri and Taloqan. In the following we will briefly describe these cities.

Sheberghan: An important trading and transit city located along the Ring Road is estimated to have a population ranging between 146,333-175,599 inhabitants. ${ }^{5}$ The city is majority Uzbek with sizeable Tajik, Pashtun, Hazara and Arab population segments. Sheberghan is dominated by one patron, Abdul Rashid Dostum, Vice President and former Northern Alliance leader. ${ }^{6}$ In addition to its location along the Ring Road, Sheberghan also controls access to the Andhkoy border crossing with Turkmenistan. Security in the city is comparatively good, though districts surrounding the city have experienced intense fighting repeatedly threatening the city.

Mazar-e Sharif: An ancient Silk Road city, it is the dominant trading and transit centre of the North and North-East. Its population is estimated between 577,500 693,000 inhabitants. ${ }^{7}$ The city is ethnically mixed with unclear ethnic majorities. The dominant ethnic groups are the Tajiks, Uzbeks and Hazaras. Mazar-e Sharif is located

\footnotetext{
${ }^{5}$ http://unhabitat.org/books/soac2015/ (P.12)

${ }_{6}^{6}$ General Dostum is also heading the Junbesh-e Milli party, a mostly Uzbek political party.

${ }^{7}$ http://unhabitat.org/books/soac2015/ (P.12)
} 
along the Ring Road and is connected to the Hairatan border crossing to Uzbekistan. The city and the surrounding Balkh Province are dominated by the provincial governor and main patron in the area, Gen. Atta Mohammed Noor, also a former Northern Alliance leader and leading member of Jamiat-e Islami party. Security in and around the city is remarkably good.

Pul-i Khumri: A further important trading and transit hub, Pul-i Khumri is located at the merger of the Ring Road and the Kunduz Highway leading via Kunduz City to the Shir Khan Bandar border crossing with Tajikistan. Pul-i Khumri (and neighbouring Baghlan-i Jadid) has an industrial background dating back to the 1950s. A cement factory, and artisanal coal mining, in the vicinity of the city still bear witness to these attempts at industrialisation. Pul-i Khumri's population is estimated at $184,395-$ $221,274 .{ }^{8}$ As is the case with all other cities of the North and North-East, it is ethnically mixed, with Tajik, Pashtun and Hazara majorities. There is no single dominant patron controlling the city, instead a number of Tajik, Hazara and Pashtun powerbrokers appear to vie for power in the city. Of all the four survey cities, Pul-i Khumri's security is worst. Though not controlled by the insurgents, the city has repeatedly received incoming fire from insurgents positioned to the West and NorthWest of the city.

Taloqan: A lesser provincial centre is located off the Ring Road along the KunduzTaloqan Highway without direct access to border crossings. Taloqan, as well, is ethnically mixed, with Tajiks and Uzbeks vying for control and dominance in the city (with other ethnic groups being comparatively insignificant in relation to the aforementioned two). Taloqan, too, lacks a dominant patron. Security, though, is comparatively good.

\footnotetext{
${ }^{8}$ http://unhabitat.org/books/soac2015/ (P.12)
} 


\begin{tabular}{|c|c|c|c|c|c|}
\hline City & No. & $\begin{array}{c}\text { Guzar Name / } \\
\text { location }\end{array}$ & $\begin{array}{l}\text { Number of } \\
\text { households }\end{array}$ & $\begin{array}{c}\text { Permanent } \\
\text { population of } \\
\text { guzar }\end{array}$ & $\begin{array}{c}\text { Old } \\
\text { traditional vs. } \\
\text { new guzar }\end{array}$ \\
\hline \multirow{5}{*}{$\begin{array}{l}\frac{1}{\pi} \\
\frac{\pi}{00} \\
\frac{0}{0} \\
\frac{0}{0} \\
\frac{D}{n}\end{array}$} & 1 & District 1 & 200 & 5000 & 13 -years old \\
\hline & 2 & District 1 & 350 & 750 & 5 years ago \\
\hline & 3 & District 2 & 250 & 3700 & $\begin{array}{c}\text { Old (some } \\
\text { new residents }\end{array}$ \\
\hline & 4 & District 2 & 1200 & 15000 & $\begin{array}{l}\text { Old (some } \\
\text { new } \\
\text { residents) }\end{array}$ \\
\hline & 5 & District 3 & 200 & 2700 & Old \\
\hline \multirow{7}{*}{ 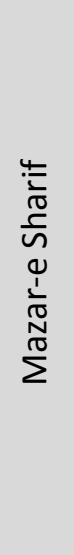 } & 6 & District 4 & 200 & 1800 & Old \\
\hline & 7 & District 4 & 373 & 6000 & 15 -years old \\
\hline & 8 & District 5 & 130 & 3250 & Old \\
\hline & 9 & District 5 & 200 & 2480 & 20-years old \\
\hline & 10 & District 8 & 260 & 4600 & Old \\
\hline & 11 & District 10 & 420 & 4000 & $\begin{array}{l}\text { About } 20 \\
\text { years ago }\end{array}$ \\
\hline & 12 & District 10 & 300 & 1200 & Old \\
\hline \multirow{5}{*}{ 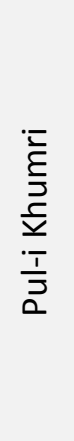 } & 13 & District 1 & 250 & 1100 & Old \\
\hline & 14 & District 1 & 700 & 3000 & Old \\
\hline & 15 & District 3 & 350 & 2000 & Old \\
\hline & 16 & District 3 & 100 & 1200 & $\begin{array}{c}\text { Old; some } \\
\text { new residents }\end{array}$ \\
\hline & 17 & District 4 & 150 & 1000 & $\begin{array}{c}\text { 1991; some } \\
\text { new residents }\end{array}$ \\
\hline \multirow{5}{*}{$\begin{array}{l}\frac{5}{\pi} \\
\frac{0}{0} \\
\frac{0}{10}\end{array}$} & 18 & District 1 & 170 & 4200 & $\begin{array}{c}\text { Old (some } \\
\text { new residents }\end{array}$ \\
\hline & 19 & District 1 & 300 & 1600 & $\begin{array}{l}\text { Old (some } \\
\text { new } \\
\text { residents) }\end{array}$ \\
\hline & 20 & District 3 & 150 & 1500 & $\begin{array}{l}\text { Old (some } \\
\text { new } \\
\text { residents) }\end{array}$ \\
\hline & 21 & District 3 & 80 & 900 & $\begin{array}{l}\text { Old (half are } \\
\text { new residents }\end{array}$ \\
\hline & 22 & District 6 & 92 & 840 & 5 years ago \\
\hline
\end{tabular}

Table 1: Overview of surveyed guzars 


\section{Sample description}

The survey guideline interviews were conducted on three levels: (a) with 22 heads of guzars (appointed representatives of streets), (b) with 195 household representatives; interviews were conducted in the same guzars the heads of which we interviewed; and (c) with 36 government and civil society representatives (nine such representative interviewed in each of the four cities).

\section{Interviews with guzar heads}

In the course of the survey we interviewed 22 heads of guzars. Each Afghan city is subdivided into so-called guzars - a clearly defined street or street section (for longer roads). Each guzar has a representative, a wakil-e guzar (in Mazar-e Sharif also referred to as kalantar). The wakil-e guzar is suggested by the community and approved by the Municipality. He represents the guzar towards authorities and reports to the NDS and other security departments if needed, and vice versa, represents the interests and conveys the requests of the city authorities towards the inhabitants of the guzar. The team surveyed seven guzars in Mazar-e Sharif (the largest city in North-East Afghanistan and in the AHRRAO survey) and five guzars each in Sheberghan, Pul-i Khumri and Taloqan. The 22 surveyed guzars have an average of 6,400 households (see Table 1) and thus represented an estimated population of 68,000 people (based on an average of 10 members per household). It is testimony to Afghanistan's rapid urbanisation that roughly half of the surveyed guzars are less than 20 years old, and nearly three quarters (old and new guzars) have received massive inflows of new city dwellers from the surrounding countryside.

\section{Interviews with household representatives}

The core of the survey is the interviews conducted with household representatives in the aforementioned 22 guzars. The interviews with the household representatives were conducted in the same 22 guzars where we interviewed the head (wakil-e guzar) of the guzar. Within each guzar, the survey team interviewed both households which have members that have migrated, as well as households with no members on migration. The aim was to understand what prompts, but also what dissuades households from sending or permitting their members to migrate. Within each guzar, the survey teams were instructed to equally distribute interviews between households with and without emigrants. Ultimately some $61 \%$ of all interviews were conducted with migrant households, while some $39 \%$ were with households without migrants (see Table 2). Households with migrants are therefore somewhat overrepresented in our sample as compared to our original schedule. 
Of the 195 household interviews, 44 were conducted in Sheberghan, 66 in Mazar-e Sharif (the largest city of the four surveyed urban centres), 43 in Pul-i Khumri and 42 in Taloqan. In many respects the profile of the interview partners and interviewed households is relatively similar in the four cities. The average age of respondents in the four cities ranges between 33 and 35 years (with the youngest interviewed respondent being 17, the oldest 75 years old), the average household size is between 10 to 11 members (smallest household 2, largest household 21). In all three cities between $59 \%$ and $62 \%$ of interviewed households had one or more members who have migrated. ${ }^{9}$

\footnotetext{
${ }^{9}$ We have no precise breakdown of the gender or the approximate number of migrated household members.
} 


\begin{tabular}{|c|c|c|c|c|c|c|}
\hline & Profession & Education & Ethnicity & $\begin{array}{c}\text { Age } \\
\text { (average) }\end{array}$ & $\begin{array}{l}\text { HH size } \\
\text { (average) }\end{array}$ & $\begin{array}{l}\text { HH member } \\
\text { on migration }\end{array}$ \\
\hline $\begin{array}{l}\text { Shiberghan } \\
\text { (44 intv's) }\end{array}$ & $\begin{array}{c}\text { Small business: } \\
\text { 23\% } \\
\text { Labourer: 21\% } \\
\text { Government: } \\
\text { 32\% } \\
\text { Professional: 5\% } \\
\text { Student: 5\% } \\
\text { Unemployed: 9\% } \\
\text { Other: } 7 \%\end{array}$ & $\begin{array}{l}\text { Higher: } 48 \% \\
\text { Middle: } 20 \% \\
\text { Lower: } 32 \%\end{array}$ & $\begin{array}{c}\text { TAJ: } 27 \% \\
\text { UZB: } 52 \% \\
\text { PAS: } 2 \% \\
\text { HAZ: } 9 \% \\
\text { Other: } 9 \%\end{array}$ & 35.34 & 10.54 & $\begin{array}{l}\text { Yes: } 26(59 \%) \\
\text { No: } 18(41 \%)\end{array}$ \\
\hline $\begin{array}{l}\text { Mazar-e Sharif } \\
\text { (66 intv's) }\end{array}$ & $\begin{array}{c}\text { Small business: } \\
\text { 26\% } \\
\text { Labourer: } 24 \% \\
\text { Government: } \\
14 \% \\
\text { Professional: } 6 \% \\
\text { Student: } 11 \% \\
\text { Unemployed: } 8 \% \\
\text { Other: } 12 \%\end{array}$ & $\begin{array}{l}\text { Higher: } 38 \% \\
\text { Middle: } 41 \% \\
\text { Lower: } 20 \%\end{array}$ & $\begin{array}{l}\text { TAJ: } 61 \% \\
\text { UZB: } 8 \% \\
\text { PAS: } 5 \% \\
\text { HAZ: } 21 \% \\
\text { Other: } 6 \%\end{array}$ & 34.14 & 10.36 & $\begin{array}{l}\text { Yes: } 41(62 \%) \\
\text { No: } 25(38 \%)\end{array}$ \\
\hline $\begin{array}{l}\text { Pul-i Khumri } \\
\text { (43 intv's) }\end{array}$ & $\begin{array}{c}\text { Small business: } \\
\text { 16\% } \\
\text { Labourer: } 10 \% \\
\text { Government: } 7 \% \\
\text { Professional: } 7 \% \\
\text { Student: } 35 \% \\
\text { Unemployed: } \\
\text { 16\% } \\
\text { Other: } 9 \%\end{array}$ & $\begin{array}{l}\text { Higher: } 36 \% \\
\text { Middle: } 38 \% \\
\text { Lower: } 24 \%\end{array}$ & $\begin{array}{l}\text { TAJ: } 42 \% \\
\text { UZB: } 0 \% \\
\text { PAS: } 16 \% \\
\text { HAZ: } 33 \% \\
\text { Other: } 9 \%\end{array}$ & 34.2 & 11.23 & $\begin{array}{l}\text { Yes: } 26(60 \%) \\
\text { No: } 17(40 \%)\end{array}$ \\
\hline $\begin{array}{l}\text { Taloqan } \\
\text { (42 intv's) }\end{array}$ & $\begin{array}{c}\text { Small business: } \\
\text { 29\% } \\
\text { Labourer: } 19 \% \\
\text { Government: } \\
12 \% \\
\text { Professional: } 5 \% \\
\text { Student: } 12 \% \\
\text { Unemployed: } \\
12 \% \\
\text { Other: } 7 \%\end{array}$ & $\begin{array}{l}\text { Higher: } 56 \% \\
\text { Middle: } 23 \% \\
\text { Lower: } 21 \%\end{array}$ & $\begin{array}{c}\text { TAJ: } 71 \% \\
\text { UZB: } 17 \% \\
\text { PAS: } 7 \% \\
\text { HAZ: } 0 \% \\
\text { Other: } 5 \%\end{array}$ & 33.48 & 11.08 & $\begin{array}{l}\text { Yes: } 25(60 \%) \\
\text { No: } 17(40 \%)\end{array}$ \\
\hline $\begin{array}{l}\text { Total } \\
\text { (195 intv's) }\end{array}$ & $\begin{array}{c}\text { Small business: } \\
\text { 24\% } \\
\text { Labourer: } 19 \% \\
\text { Government: } \\
16 \% \\
\text { Professional: } 7 \% \\
\text { Student: } 15 \% \\
\text { Unemployed: } \\
11 \% \\
\text { Other: } 9 \%\end{array}$ & $\begin{array}{l}\text { Higher: } 44 \% \\
\text { Middle: } 32 \% \\
\text { Lower: } 24 \%\end{array}$ & $\begin{array}{c}\text { TAJ: } 51 \% \\
\text { UZB: } 18 \% \\
\text { PAS: } 7 \% \\
\text { HAZ: } 16 \% \\
\text { Other: } 7 \%\end{array}$ & 34.28 & 10.64 & $\begin{array}{c}\text { Yes: } 118 \\
(61 \%) \\
\text { No: } 77(39 \%)\end{array}$ \\
\hline
\end{tabular}


Table 2: Overview of the household interview sample in the four survey cities (Sheberghan, Mazar-e Sharif, Pul-i Khumri and Taloqan)

On other variables, however, the samples in the three cities show more significant variation. All cities are ethnically mixed, the actual ethnic composition varies, however, quite significantly between the four cities. The samples in Mazar-e Sharif and Taloqan have an absolute Tajik majority, Sheberghan has an absolute Uzbek majority, while there is only a relative majority of Tajiks in Pul-i Khumri, with the second largest group being Hazaras there. These ethnic compositions probably roughly reflect the actual demographic makeup of these cities. However, lacking a proper census, we have no possibility to verify this. There is, however, considerable variation between the surveyed cities with regard to the professional and educational composition of the sample. Once again, it is not clear to what extent this variation reflects actual differences between the cities, or is the result of random distribution within a relatively small sample.

For example, the proportion of small businesses (16\%) and labourers (10\%) is lowest, while the percentage of unemployed (16\%) is the highest in Pul-i Khumri, which is also the most insecure of the four cities (the averages for the sample are $24 \%, 19 \%$ and $11 \%$ respectively). The lower proportion of small business owners and labourers, and the higher proportion of unemployed in the Pul-i Khumri sample, may be the result of the comparatively higher insecurity, or a historical residue of Pul-i Khumri's industrial and mining past. However, it may also simply be a chance outcome.

\section{Interviews with government representatives}

Lastly we also conducted a total of 36 interviews (nine interviews in each city) with representatives of important provincial-level institutions and decision-makers, including government officials, representatives of the Provincial Council, the Ulema, civil society, NGOs and international organisations. As part of this series of interviews, in each city / provincial centre we interviewed representatives of the following institutions / sectors:

- Provincial Administration

- Department of Economy (DoEc), Department of Education (DoE), Department of Labour and Social Affairs (DoLSA), Department of Women's Affairs (DoWA)

- Provincial Afghan National Police (ANP)

- Municipality

- Provincial Council (PC)

- Representative of a civil society organisation

- NGOs, International Organisations 
The aim of these interviews was to understand how representatives of these institutions assessed the migration problem, and whether they carried out activities to prevent or dissuade people from migrating.

\section{Empirical results}

\section{General perceptions, migration frequency and migration patterns}

In this section we provide a general overview based on the household-level survey of how respondents assess and describe their situation. In particular, we consider three areas: (a) the economic outlook of the household (Question 4 of the survey), (b) the assessment of the security situation by the interview partner (Question 9), and (c) expectations for the future of the household (Question 7).

\section{Economic outlook of household}

Most respondents (133 respondents or $68 \%$ of the household survey) described the economic situation of their household in negative terms:

"[My income], it is not enough for my household. If I earn the costs for the breakfast, then I have to worry about the lunch. If I find the expenses for lunch, I will worry about dinner" (8 Feb 2016, Mazar-e Sharif).

This situation that is not outright hunger or full deprivation, but nonetheless precarious, was described by another interview partner, a 21-years-old shopkeeper, as follows:

"Living and being alive are different things. Now we are alive, but we are not living" (7 Feb 2016, Mazar-e Sharif).

A relative minority of 62 respondents (32\%) are satisfied with their current circumstances, though this is partly due to relatively low expectations and a religious outlook on life. Two quotes exemplify this stance:

"Alhamdulillah, it suffices. We don't have any serious problem" (20 years-old student, Pul-i Khumri, 23 Feb 2016).

"Yes, it [our household's income] is good but it is not enough for a good life" (38-years-old government official, Taloqan, 3 March 2016).

\section{Security assessment}

Turning to security, respondent assessments were generally bleak. In fact, we found no upbeat, optimistic assessment among the 195 household level interviews. As a 
32-year-old wood seller from Pul-i Khumri, the city with the worst security in the survey, put it:

"The security situation is deteriorating day by day. There is fighting near our houses. Sometimes the projectiles of the enemies [the Taliban] hit our houses. We worry about our children and our household" (23 February 2016).

Several respondents explicitly mentioned not just their fear of the Taliban, but also of the Islamic State. Some blamed the Afghan government for failing them:

"The security situation is deteriorating day by day and the Government didn't even succeed in appointing some ministers yet. Our government doesn't have a clear policy for the future of the country" (22 years-old student, Mazar-e Sharif, 8 February 2016).

Yet others blame the meddling of foreigners:

"The security situation is bad. The elders cannot agree with each other. Turkey, Saudi Arabia, Pakistan and Iran support the Taliban and ISIS and [as a result] they become more powerful and so insecurity increases, too" (24 years-old unemployed, Sheberghan, 23 February 2016).

"The situation is very bad. America strengthens the Taliban and the Government to annihilate the people. In the past, the war was in remote areas but it has now reached Pul-i Khumri City. People migrate due to this insecurity. If there were jobs and security, why would they do it?" (50 years-old architect, Mazar-e Sharif, 9 February 2016).

The fall of Kunduz on 28 September 2015 also clearly had a strong and negative impact on sentiments, with many respondents fearing that their city, too, could suffer a similar fate:

"[The security situation] is negative. There is war in some provinces and after the battle of Kunduz, insecurity has increased. People in each province think that they may be the next after Kunduz. Our security commanders travelled to India and there are some rumours that Sheberghan City and Jawzjan Province may be seized by the Taliban. People are very worried about the situation. There is fighting every day and the Taliban are gaining more power. Fighting takes place in Aqcha, Darzab and some other districts of Jawzjan Province every day" (19 years-old shopkeeper, Sheberghan, 23 February 2016).

While the security assessment of practically all respondents was negative, those interview partners living in the more secure cities of Mazar-e Sharif or Taloqan acknowledged and were grateful for the better local security. This did not, however, change their overall negative assessment: 
"The spring doesn't come with one flower only. Although, there is good security in our province [Balkh], we should also consider [the situation in] the other provinces. I hope one day we won't hear bad news about our kith and kin here. Unfortunately, there are explosions and bombs everywhere nowadays. Generally, our country is facing a conflict" (47 years-old selfemployed man, Mazar-e Sharif, 7 February 2016).

\section{Expectations for the future}

When asked about expectations for the household's future, only five interview partners (3\%) gave positive assessments. These assessments, however, related to the economic situation of the household and not to security. A 28 year-old government employee considered both aspects:

"My household will have a bright future because we don't have economic problems, Alhamdulillah. But, we are afraid of the security situation. The security situation is deteriorating gradually. Consequently, this insecurity will destroy everything" (Taloqan, 3 March 2016).

A further 34 interview partners (17\%) refused to speculate about the future. Some did this on religious grounds:

"We rely on God. Everything will happen according to God's will. We cannot foresee the future" (50 years-old real estate dealer, Mazar-e Sharif, 7 February 2016).

Others responded in the conditional:

"If the Government doesn't take action, the situation will deteriorate further. Our leaders just make promises to people every day, but they don't act upon their promises" (24 year-old baker, Mazar-e Sharif, 7 February 2016).

The overwhelming majority of interview partners (156 interviewees or $80 \%$ of the sample), however, had very negative expectations with regard to the future and stated this explicitly. The overall impression was that an entire country is sinking into depression and gloom. Here are two exemplary quotes:

"Our future is dark. The situation is deteriorating. There is no employment. People can hardly find money to buy food. As long as there is insecurity, there will be unemployment too. There are explosions and suicide bombings every day. People say that next year will be the bloodiest year of the last decade" (33 year-old shopkeeper and community leader, Mazar-e Sharif, 10 February 2016). 
"We will not have any bright future in this country. Everything is dark. So, the future of our household is not clear either" (34 years-old mullah, Pul-i Khumri, 18 February 2016).

Some explicitly link negative expectations regarding the future to migration.

"My household will have a dark future because we have been sending our young generation to European countries in order to work there. But we don't know whether European countries will accept them or not. So we cannot predict the future of our households and of our country" (55 years-old shopkeeper, Pul-i Khumri, 23 February 2016).

"I don't see a good future for myself. If the situation gets worse, I will have to sell all my property and migrate" (45 years-old farmer and landowner, Sheberghan, 25 February 2016).

\section{City, guzar and household characteristics and migration frequency}

\section{City characteristics and the likelihood of migration}

Lacking a census and representative surveys in Northern Afghanistan, we relied on interviewing guzar heads to estimate the prevalence of migration in the surveyed cities (see Table 3). Given the close contacts of wakil-e guzars with the households of their guzar, asking them for estimates of demographic patterns within their guzars is probably the easiest and most accurate way of assessing trends in the urban Afghan context.

An initial look at migration patterns, as estimated by interviewed wakil-e guzars for their own guzars, shows limited variance between the four cities and between the guzars of each city. On a scale of 1 to 5 , where 1 represents the lowest number of households having at least one member on migration (none of the households have migrant members) and 5 the highest (all households have migrant members), Taloqan (Takhar Province) reached the highest assessments followed by Mazar-e Sharif (Balkh Province). Both cities are comparatively safe and peaceful. The two cities Pul-i Khumri and Sheberghan most affected by conflict and violence have seen significantly less household members migrate, with most wakil-e guzars interviewed estimating that only "some households" (i.e. less than half of households of a guzar) had migrant members. According to this rough assessment, only Sheberghan appears to have sent marginally more migrants out of Afghanistan than Pul-i Khumri. In spite of the difference between the cities and the different degrees to which they have been affected by insecurity and migration, it is remarkable that no guzar remained unaffected by migration. 
The survey team also asked guzar heads to assess the degree to which youth unemployment was a problem in the guzar and the proportion of households that had been food deficient for some time during the previous year (we understand this as a proxy for poverty). With regard to youth unemployment, there is virtually no variation between the cities and the guzars: almost all wakils interviewed judged the problem to be "very serious" (the most negative assessment offered to respondents). The question as to whether some households were food deficient in the past year, however, shows some variance.

The least affected in terms of food deficiency appears to be Mazar-e Sharif, an important trading hub since ancient times, and located close to a border crossing point with Uzbekistan (Hairatan). Mazar is also the most secure city of the sample. The second least affected is, in spite of its somewhat precarious security situation, Sheberghan, close to the Andhkoy border crossing point to Turkmenistan. Taloqan, a relatively remote provincial centre off the road from Kunduz and easily cut off from the main roads when fighting in Kunduz escalates, appears to be less well off than either Mazar or Sheberghan. Lastly, Pul-i Khumri, located at the merger of the Afghan Ring Road with a branch leading to the Shir Khan Bandar border crossing with Tajikistan, is least well off - at least as judged by the sample. 


\begin{tabular}{|c|c|c|c|c|c|}
\hline \pm & $\begin{array}{c}\text { No } \\
\text {. }\end{array}$ & $\begin{array}{c}\text { Guzar Name } \\
\text { / location }\end{array}$ & $\begin{array}{l}\text { Estimated number of } \\
\text { households with at least } \\
\text { one migrant member }\end{array}$ & $\begin{array}{c}\text { Estimated severity of } \\
\text { youth unemployment in } \\
\text { the guzar }\end{array}$ & $\begin{array}{l}\text { Estimated number of } \\
\text { households without } \\
\text { enough food last year }\end{array}$ \\
\hline \multirow{5}{*}{ 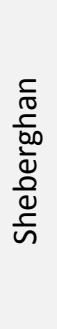 } & 1 & District 1 & Some households & Serious problem & Less than half \\
\hline & 2 & District 1 & (about) half of households & Very serious problem & Most households \\
\hline & 3 & District 2 & Some households & Very serious problem & Less than half \\
\hline & 4 & District 2 & Some households & Very serious problem & Most households \\
\hline & 5 & District 3 & Some households & Very serious problem & Less than half \\
\hline \multirow{7}{*}{ 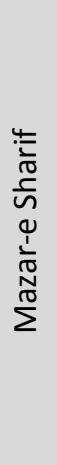 } & 6 & District 4 & Most households & Serious problem & Less than half \\
\hline & 7 & District 4 & Some households & Very serious problem & Less than half \\
\hline & 8 & District 5 & Most households & Very serious problem & Most households \\
\hline & 9 & District 5 & Some households & Very serious problem & Most households \\
\hline & 10 & District 8 & Some households & Very serious problem & Less than half \\
\hline & 11 & District 10 & All households & Very serious problem & Less than half \\
\hline & 12 & District 10 & Some households & Very serious problem & Less than half \\
\hline \multirow{5}{*}{ 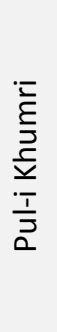 } & 13 & District 1 & Some households & Very serious problem & Most households \\
\hline & 14 & District 1 & Some households & Very serious problem & Most households \\
\hline & 15 & District 3 & Some households & Very serious problem & Most households \\
\hline & 16 & District 3 & Some households & Very serious problem & Most households \\
\hline & 17 & District 4 & Some households & Very serious problem & All households \\
\hline \multirow{5}{*}{$\frac{\frac{1}{0}}{\frac{\pi}{0}}$} & 18 & District 1 & All households & Very serious problem & Most households \\
\hline & 19 & District 1 & (about) half of households & Very serious problem & Most households \\
\hline & 20 & District 3 & Some households & Very serious problem & Most households \\
\hline & 21 & District 3 & (about) half of households & Very serious problem & Less than half \\
\hline & 22 & District 6 & All households & Very serious problem & Most households \\
\hline
\end{tabular}

Table 3: Estimates by wakil-e guzars of prevalence of migration, youth unemployment and food shortages of households within their guzar

The reason for the low performance of Pul-i Khumri might be the bad security situation or, as mentioned, its industrial past. The city is under virtual siege from the south and west and has for several months regularly received incoming fire, though the insurgents never actually took over the city, as they did with Kunduz. The comparison of the four cities shows no clear pattern linking poverty (estimated through food deficiency) and the frequency of households having members on migration: Pul-i Khumri, the poorest city of the survey, has the least households with migrants, whereas Taloqan, the second poorest city of the survey, had the most. 
Mazar-e Sharif and Sheberghan, both comparatively better off, were in between the two extremes (Pul-i Khumri and Taloqan).

\section{Guzar characteristics and the likelihood of migration}

Turning to the guzar level and looking at poverty, as proxied for guzars through the estimated food deficiency of households, and the likelihood of households having migrant members, we find no link between the estimated poverty of a guzar and the frequency of migration: households in poorer guzars are no less likely to have members on migration than households in somewhat better off guzars. This does not mean that such a link does not exist - after all the investigation is not a representative quantitative survey. It suggests, however, that even if such a link does exist, i.e. that greater poverty inhibits households from sending members to migrate, this link is probably not very strong. A strong link would have been likely picked up even by this limited qualitative sampling.

\section{Individual household-level characteristics and the likelihood of migration}

Using the qualitative household-level interviews, we checked for a further possible link: (a) between education levels of the household representative interviewed and the likelihood of households having members on migration and (b) between the occupation of the household representative interviewed and the likelihood of households having members on migration (see Table 4). Both features can be understood as proxies for the economic situation of a household (see also Section "Research questions to be investigated").

\begin{tabular}{lccc} 
Occupation & $\begin{array}{c}\text { HH member on } \\
\text { migration }\end{array}$ & $\begin{array}{c}\text { No HH member } \\
\text { on migration }\end{array}$ & $\begin{array}{c}\text { Number of } \\
\text { respondents }\end{array}$ \\
\hline Small business & $54 \%$ & $46 \%$ & 46 \\
\hline Labourer & $62 \%$ & $38 \%$ & 37 \\
\hline Government & $68 \%$ & $32 \%$ & 31 \\
\hline Professional & $54 \%$ & $46 \%$ & 13 \\
\hline Student & $59 \%$ & $41 \%$ & 29 \\
Unemployed & $57 \%$ & $43 \%$ & 21 \\
\hline $\begin{array}{l}\text { Other (local } \\
\text { etc.) }\end{array}$ & & & 18 \\
\hline Survey average & $72 \%$ & $28 \%$ & 195
\end{tabular}


Table 4: Occupation of household representative interviewed and migrant members in household

With regard to education, we find no meaningful link between the education level of household representatives interviewed and the likelihood that his / her household has a migrant. Examining the occupation of interviewed household representatives and the likelihood of the household having migrant members, it seems that small business owners and the unemployed are somewhat less likely to have migrants, whereas government officials or the category "other" (mostly local elders, mullahs, etc.) are somewhat more likely to have members on migration than the survey average (61\%). Those on government pay and local notables (such as guzar heads) are likely to be somewhat better off than most labourers and might also feel more personally threatened - and thus might be more interested in establishing a "bridgehead" in a foreign country through the migration.

\section{Migration patterns}

As was mentioned in the previous sections, even though there are some differences between the four cities of the survey, the migration of household members is now so widespread in the North-East (and probably the whole of the country) that there are virtually no guzars within an urban context that have not experienced migration. But when did these people migrate and to where did they migrate?

\section{Migration destinations}

An initial analysis of the 195 interviews of the household level survey gives an answer to these questions. As a reminder, 61\% of these interviews (i.e. 118 interviews) were conducted with households with at least one member that had migrated from Afghanistan to a foreign country. Of the 118 households that had migrant members, 59 (or 50\%) were in Europe, of whom 30 (25\%) were in Germany (Question 33). Those who did not migrate to Europe chose other destinations, most importantly Iran, Turkey, the Gulf Arab states, Indonesia or the US. A few of those who at the time of the survey were in Turkey or Iran, reportedly considered migrating further to Europe. These figures confirm what is obvious from the already quoted Eurostatstatistics: the migration of Afghans to Europe and within Europe to Germany is a very widespread phenomenon. The migration of Afghans does not only effect Europe, but to a similar degree also other countries aside of Europe.

\section{Time of migration}

Of the 118 households with migrant members, $81 \%$ have migrated in the last two years, i.e. as part of the recent migration wave (Question 35). The remaining 19\% (members of 22 households) migrated prior to the recent dramatic escalation, with the oldest migrant living since 1981 in Canada (apparently a person who left the 
country just after the Soviet invasion). These figures confirm from a limited regional Afghan perspective the dramatic escalation of outmigration since 2014.

\section{Potential for further migration}

We further coded interviews for households actively considering sending members to migrate outside of Afghanistan (Question 19). Of the 195 interviewed households, 50 (26\%) actively considered sending / allowing more members to migrate (irrespective of whether they already had migrants or not), while another 30 (15\%), would consider migration, should the (economic or security) situation worsen further.

\section{Concrete threats and migration decision}

While worries about the poor security situation were common, of the 195 households interviewed, only seven interview partners mentioned concrete personal threats to a close relative (household member) as having motivated the decision to migrate. These threats include cases of legal migration as a result of ISAF employment:

"He worked with the Germans at the airport. He was in danger, so the Germans took him with them to Germany" (7 Feb 2016, Mazar-e Sharif).

Other cases seem to relate to threats by insurgents, or are the result of personal conflicts with powerful men or criminals. Here are two examples:

"He had to migrate because he was working for a construction company in insecure provinces. He was threatened several times" (18 Feb 2016, Pul-i Khumri).

Insurgents are known to threaten construction workers who either work on projects deemed by the Taliban as being in support of the government (e.g. certain roads, military installations, etc.) or simply who fail to pay taxes to them. Another example relates to a conflict with a local strongman:

"A strongmen misappropriated my land. They were threatening my son. I had to send my son away in order for him to be safe" (23 February 2016, Pul-i Khumri).

\section{Communication between migrants and family and friends in} Afghanistan

A lot has been written on the importance of mobile telephone and electronic communication, as well as the role of social media, in facilitating migration and influencing migration decisions during the current wave of migration. As an example, 
a recently published European Commission report writes the following about Syrian migrants:

"Syrians displaced in the region seem to have access to good information on available options via informal social networks and family members and friends who had earlier embarked on the journey to Europe. For them, social media has developed into the main means of communication, with individuals frequently having Facebook, Skype, WhatsApp and Viber accounts. Once they have arrived in transit countries such as Egypt, Turkey, Greece, Hungary, or Italy, information about the completed leg of their journey is shared online including pictures of fake or altered travel documents; used boats and other means of transportation; drawings and maps of the routes; information about departure times and starting points for assisted journeys, as well as the phone numbers of smugglers and brokers located in transit countries. "10

Our interviews confirm similar mechanisms at work with regard to Afghan migrants. ${ }^{11}$ In our interviews we specifically also considered communication between migrants and their household members and the feedback migrants provided to those who remained at home. Thus of the 59 households who reported having migrant household members in the EU, we asked if they were in regular contact with their migrant member in the EU. 57 respondents confirmed such regular contacts (Question 38). We then asked what feedback did migrant members provide to those at home: Did they encourage them to join them? Or did they try to dissuade them from coming?

Of the 57 respondents who confirmed having regular contacts with their migrant household members, 38 mentioned that their relatives had tried to convince them to join him or her:

"Yes, they motivate us to join them. They talk about the good security situation in European countries and the green lands there" (3 March 2016, Taloqan).

As a result, some are inclined to migrate, too.

"Yes, they motivate us. As a result, I want to migrate, too" (5 March 2016, Taloqan).

\footnotetext{
${ }^{10}$ http://ec.europa.eu/dgs/home-affairs/what-we-do/networks/european migration network/reports /docs/emn-studies/study on smuggling of migrants final report master 091115 final_pdf.pdf

${ }^{11}$ A recently published series on Afghan migration to Europe. Part 1 of the series also emphasises the importance of electronic and social media communication between migrants and their households in Afghanistan.
} 
Others are not interested:

"Yes, they do [try to motivate us] but we don't want to go. If someone is a good Muslim, he or she won't go to Europe. They motivate us to go since they have security and there is no war but they have dance clubs, too" (7 February 2016, Mazar-e Sharif).

The rapid communication between migrants in the EU and their households back in Afghanistan is, however, does not just serve to uncritically report good news. Negative perceptions or events and bad experiences are also quickly relayed back to Afghanistan. Of the 57 households who were regularly in touch with their migrant members, 19 reported receiving discouraging news dissuading them from migration:

"They motivated us at the beginning. But, they do not motivate us now. They believe that they will lose their religion gradually" (9 February 2016, Mazar-e Sharif).

"In the current situation, they tell us not to go there, since the situation is not good there either. Too many migrants have gone to Europe. There are also risks on the way, so they tell us not to go to Europe" (8 February 2016, Mazare Sharif).

"No, he doesn't motivate us, because the situation in European countries has deteriorated recently" (24 February 2014, Pul-i Khumri).

These quotes show that the improved communication through social media and other forms of electronic communication is not just a channel facilitating and speeding up migration, but also one potentially discouraging it - depending on whether the realities on the ground are conducive to or deter against migration. What these new forms of communication actually do is twofold: they speed up the flow of information, and they make it easier for would-be migrants and family members to verify information.

\section{Reasons for and against migration}

We coded the household interviews for push factors, i.e. negative incentives to stay in Afghanistan, as well as pull factors, i.e. positive incentives that attract respondents to migrate. There is a clear difference in the average responses between those households that have members on migration and those who do not, with regard to both pull and push factors: responses of households with members on migration are coded nearly twice as often, to any set of factors, compared to those who do not have migrant member. This means that households with migrant members have consciously considered and contemplated all issues relating to migration. They have a more structured opinion e.g. on the security and economic situation as motivating 
migration and, importantly, on the conditions awaiting migrants in the EU or non-EU migration destination countries. In the interviews we find more references to pull factors (995 in 191 interviews) than to push factors (704 references in 168 interviews) when respondents explain why they migrate.

Before proceeding further with the analysis of push and pull factors, a note on quoting is necessary. In the following we will first quote the numbers of references made with regard to a certain issue followed by the number of interviews in which references to this specific subject are made according to the following format: ([number of references]/[number of interviews]). The reason is that one interview may contain more than one reference to a certain subject. Hence, the first number (references) is as a rule higher than the second number. As an example, the coding for economic factors as "(317/149)" means that economic factors were mentioned 317 times in a total of 149 interviews.

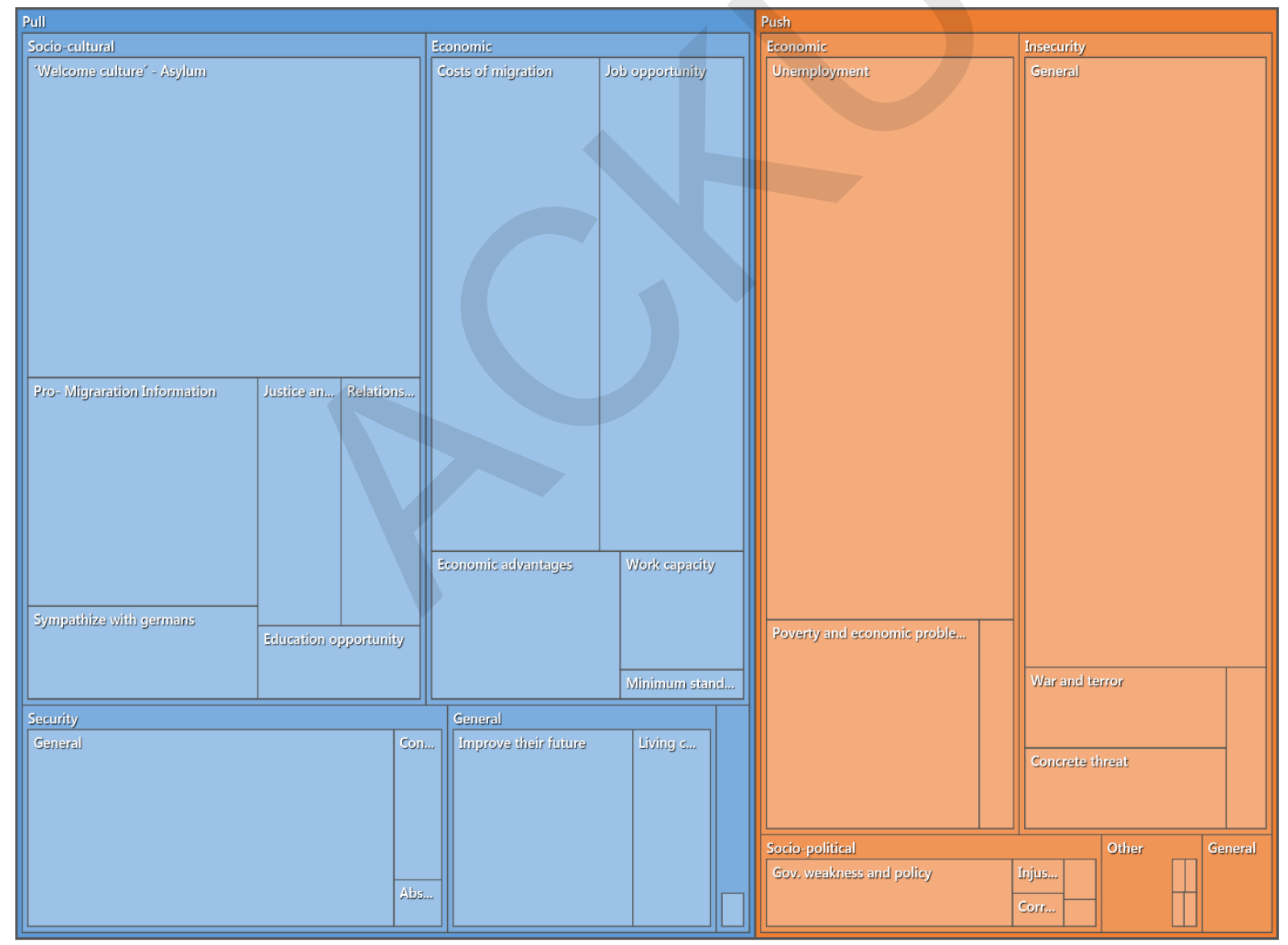

Figure 1: Tree map of push and pull factors affecting the migration decision (source: NVIVO coding of household level qualitative interviews) 


\section{Push factors}

We divide push factors into four main categories of socio-political factors, economic factors, security and general factors (see also Figure 1). Here, the category of economic factors (317/149) and insecurity (310/155) are of similar weight with sociopolitical drivers a distant third though still sizeable category (51/39). The already mentioned AAN publication on Afghan migration to Europe comes to very similar conclusions regarding the push factors motivating people to leave. ${ }^{12}$

The economic category is dominated by unemployment $(231 / 139)$ and poverty (74/59). Ten interviewees mention explicitly the need and pressure to financially support the household back in Afghanistan.

"They have to leave the country because they are jobless and there is insecurity in the country. They became hopeless. They didn't have any other solution except migrating. While they are in danger here, how can they continue living here" (3 March 2016, Taloqan).

Insecurity remains mostly a general reference (245/144). However, 24 interviewees make reference to specific threats (mostly Taliban pressure on officials and NGO workers) and a similar number of respondents relate insecurity specifically to the effects of war and terror (mostly in Sheberghan, least in Taloqan). It has to be emphasised that in the previous section above "Concrete threats and migration decision", we noted seven cases in which the migration of a household member was explained by a concrete personal threat. The coding in this section relates to a general discussion of migration reasons. In this discussion, 24 respondents mentioned personal risks to individuals as an important migration reason. Physical insecurity and economic issues are often mentioned together.

"Those who migrate have to leave the country because of security problems and unemployment. They don't migrate for joy. For example, one of my friends is in Europe now. I called him a few days ago. He was crying. He had money, but he was in danger in Afghanistan. He had to migrate because of security problem" (22 February 2016, Pul-i Khumri).

The socio-political category is defined by the perception of an incapable and weak government $(38 / 33)$ that is not trusted to solve the main security and employment problems facing the population. Injustice, discrimination of minorities and corruption by and in the government are occasionally mentioned, but they are not the main criticism levelled against the government. If the government is criticized and

\footnotetext{
${ }^{12}$ https://www.afghanistan-analysts.org/deciding-to-leave-afghanistan-1-motives-for-migration/
} 
mentioned as a migration reason, it is mostly because of its perceived weaknesses and incompetence.

"If Germans accept them, it will be better because our government is weak. Our government authorities are unable to improve the country. The future of our country is not clear." (11 February 2016, Mazar-e Sharif).

In general, however, problems associated with the Afghan Government only play a minor role as a push factor motivating people to migrate.

\section{Pull factors}

As with push factors, we divide pull factors into four major categories: socio-cultural factors, economic factors, security and general factors (see Figure 1). Interestingly, the largest and most differentiated category is made up of the socio-cultural drivers of migration (413/167). It was dominated in February and early March 2016, when we conducted our interviews, by the perception of a welcoming approach to migrants / asylum seekers specifically in Germany (206/145).

"[B]ecause European countries, especially Germany opened their borders for migrants. They are ready to accept migrants. In addition, Germany announced that it will accept thousands of migrants. So people are interested in migrating there." (10 February 2016, Mazar-e Sharif).

Under the category of socio-cultural drivers, "welcome culture" is followed by the related factor of pro-migration information (86/68) mostly received via relatives and friends (46/40). Other frequent pull-factors mentioned are positive feelings towards Germans (35/33), justice and equality in Europe (34/31), existing relationships with Germany (32/28) including diaspora contacts ${ }^{13}(13 / 13)$ and a common belief in Afghanistan that Germans and Afghans belonged to the same "Aryan" race (6/6). Education opportunities are also mentioned (20/16).

The second largest category of pull factors are economic drivers (330/171). These are dominated by decreased or affordable costs of migration (137/134) and expected job opportunities (117/79) in Europe. Economic advantages (46/43) and the expectation that Germany and other European countries have a demand for a young workforce $(24 / 22)$ are adding to the economic drivers. The social welfare system as minimum standard of living is hardly mentioned (6/6), most people expect to work.

\footnotetext{
${ }^{13}$ AAN's report (Part 1) on Afghan migration to Europe more strongly emphasises already existing diaspora contacts. Given the small sample size of the AAN report (12 in-depths interviews as opposed to 195 of the current study) this difference might be the result of chance variation.
} 
"Yes, the costs of migrating to Europe have decreased as compared to several years ago. Smugglers take a person to Greece for $\$ 1,200$ now. Yes, it is one of the main reasons that encourages people to migrate." (10 February 2016, Mazar-e Sharif).

According to our background interviews, the cost of migrating to Europe, indeed, decreased very substantially over the past two years (from about $\$ 14-17,000$ per person to sometimes below $\$ 3,000$ per person at the beginning of 2015). The main reason seems to be a decline in transaction costs - i.e. mostly bribes, fees and protection money to corrupt officials in countries that could delay or speed up the journey to Europe. The fluctuations of human smuggling prices and the possible reasons for it will be discussed in detail further below (see Section "Smuggler fees and modes of migration").

The third category of pull-factors is security (147/98). This category is dominated by general references to a peaceful and secure life (130/89). Insecurity is more differentiated as a push factor (see below).

"I think those who migrate to Europe hope for peace there. There is a sense of goodwill there towards Afghan people which is stronger there in comparison to Afghanistan and they [EU countries] are more associated with democracy, too." (25 February 2016, Sheberghan).

Finally, there are a number of general references to better living conditions and future perspectives (93/71).

\section{Reasons inhibiting migration}

We asked not only for what pushes or pulls people to migrate but also what prevents them from taking that decision for themselves or for members of their households (see Figure 2). Altogether 933 references were made in 190 interviews to inhibiting factors. We noticed, however, that some interviewees qualified inhibiting conditions by explaining that - for a variety of reasons - the factors offered by them were not effective in preventing people from migrating. We added this as "malfunctioning" inhibiting factors (283/134).

Political inhibitors consist of the risk of rejection (277/152) and patriotism (168/109). The awareness of the risk of being rejected in Europe seems to be high. However, 52 interviewees thought that this risk was mostly propaganda to discourage people from migrating and, as a consequence, 27 interviewees felt that this would not stop people from trying. There is also a high expectation among respondents that deportations would stop and that migrants could eventually stay in the EU (92/72). Media is mentioned most often as a source of information on risks of rejection (18/18). 


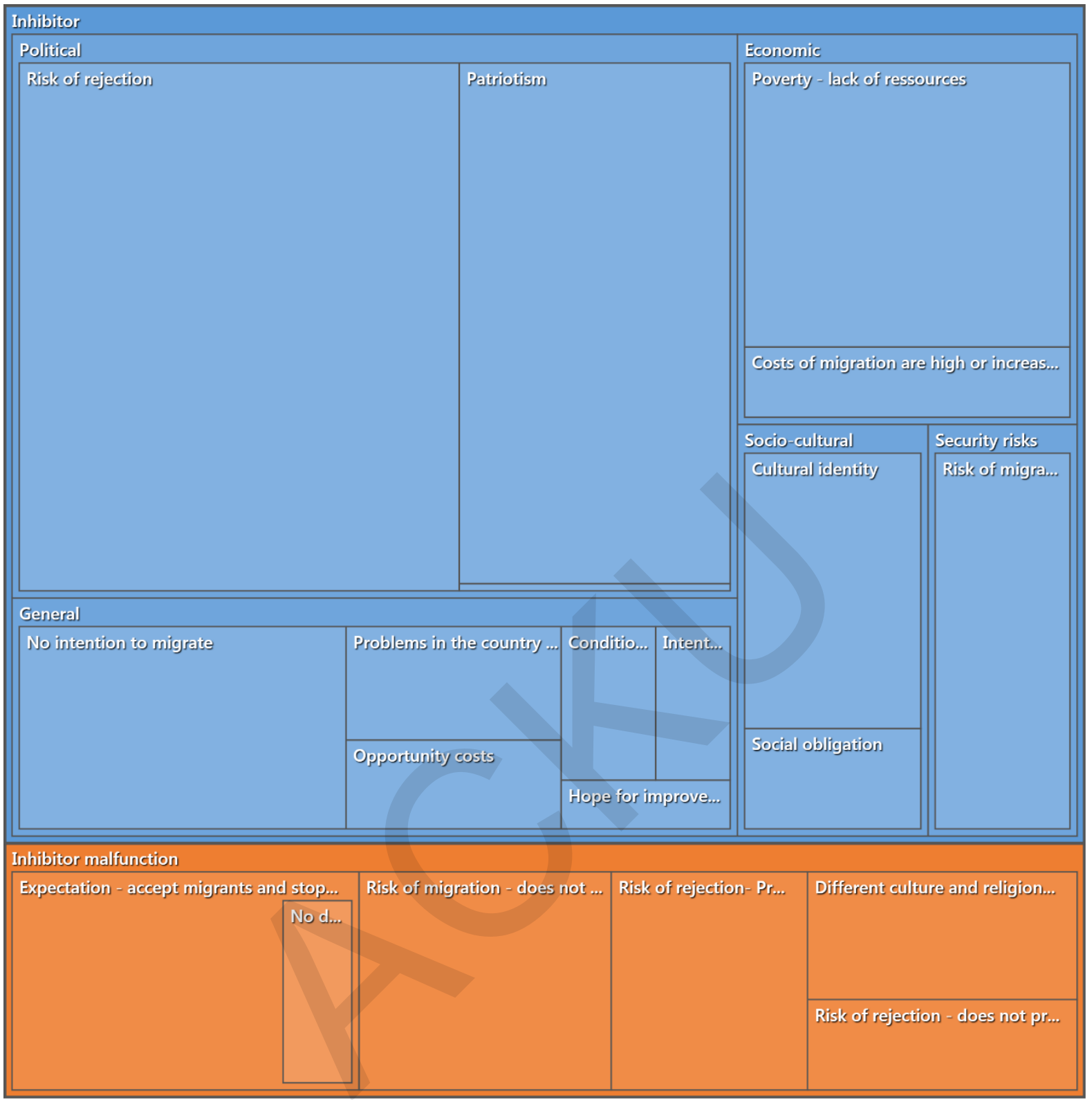

Figure 2: Tree map of factors inhibiting migration (source: NVIVO coding of household level qualitative interviews)

Many people are concerned about the consequences of rejection for the returnees themselves and for Afghan society (142/104). This ranges from material losses and problems to a heightened risk of destructive social behaviour (joining the Taliban, drug addiction and crime).

"I think, Germany will not deport migrants. If they would be deported, they [the deported migrants] may face a big problem. They will become tramps and will be miserable. They sold their properties to reach Europe. They have nothing here to come back to" (10 February 2016, Mazar-e Sharif) 
In terms of patriotism the responses are mostly straightforward and similar, underlining that the young workforce and the best and brightest are needed in Afghanistan to rebuild and defend the county.

"I love my country. We should stay and rebuild our country. Our country is like our mother. If we don't defend our country, who will defend it." (23 February 2016, Pul-i Khumri).

Economic reasons mentioned in the interviews as limiting migration are general poverty (116/79) and the specific costs of migrating legally or illicitly (29/28). Some answers seemingly contradict the impression that the costs for migration dropped significantly over the past year.

"I don't know about the past but now it is excessively expensive, since one person might spend the money of his/her whole life to get there [i.e. to Europe]" (10 February, Mazar-e Sharif).

Socio-cultural factors mentioned as inhibiting migration are the different cultural identities (63/40), including strong references to the Muslim faith (36/25), and concrete social obligations that prevent some people from migrating (23/23).

"The only thing against migration is ... Islamic beliefs that are lacking in Europe. Immigrants will be deprived of their country's legacy." (7 February 2016, Mazar-e Sharif).

However, we also noted a roughly similar number of statements explicitly denying the importance of cultural differences and religion in dissuading people from migration (42/42).

"Yes, I know there are some differences. But Germans do not care about the religion and language of asylum seekers. In fact, those who migrate there should learn their language [i.e. the language of Germans] and familiarize themselves with the German culture." (22 February 2016, Pul-i Khumri).

In terms of security risks involved in migrating, roughly as many respondents consider this to be an inhibiting condition (66/53) as there are respondents referring to this as an issue that does not stop people from migrating (67/64).

"Yes, I know about risks and dangers [of migration]. There are very many risks staying in this country, too, but if we get there, we will be at peace and at least we will not be threatened by insecurity." (25 February 2016, Sheberghan).

Finally, the category "general" contains a number of more general disincentives that overlap with more than one of the categories discussed above. First, there are general statements by interviewees that they had no intention of migrating (87/69). 
The next largest sub-group of more general disincentives is made up by those who anticipate general problems in the receiving countries (32/26). Then there are respondents who explain their decision to stay via the opportunity costs of migrating: they have material (like land) or non-material (like education, job or status) values to lose (25/21) should they decide to migrate. And then there are those who hope that things will not get worse $(15 / 15)$ or hope for improvements in the future (11/11).

"I have land and an inheritance here. I cannot leave them. Then, I also have to finish my education because I cannot afford to continue my education in foreign countries." (18 February 2016, Pul-i Khumri).

\section{Attitudes of the Afghan Government}

\section{Opinions of provincial and city-level decision makers}

Generally the opinions of the provincial and city-level decision-makers do not seem to significantly differ from the opinions of ordinary household representatives. Their opinions are based on personal experiences and prejudices. Security and economic reasons are thus the most prevalent explanations offered by these decision-makers and officials:

"The major reasons for people's migration to Europe are unemployment, poverty and insecurity. Since this new government was elected the security situation of the country has deteriorated. Beside this, unemployment will harm society, too" (University of Baghlan, 22 February 2016, Pul-i Khumri).

Only few have a differentiated understanding, derived from personal contact with would-be migrants:

"I work in Takhar province, here the reason for migration is mostly joblessness. The Government hasn't been able to implement great projects to provide jobs for the youth. In the Passport Section I ask youth why they want to migrate and they say because of "joblessness". Some people go because they are afraid of war; they go either with their family or alone. The lack of jobs and insecurity are the main reasons for migration" (ANP Headquarters, 3 March 2016, Taloqan).

Importantly, none of the government departments and other organisations or institutions interviewed have tackled the migration issue in any systematic way. 


\section{Preventive activities conducted by provincial and city-level institutions}

There is very little done in terms of preventing migration. Some interviewed officials openly admit this:

"We have no plan and haven't conducted any activities. The Ministry of Refugees and Repatriation is a symbolic ministry, it doesn't have a budget. In 2016 the total expenditure of the DRR in Takhar is AFN 600,000 (approx. $€$ $7,700)$ without salaries, but which includes the rent of the office; fuels and other tools are supplied. Unfortunately the Ministry of Refugees doesn't have any facilities for emigrants and can't provide any either. There is nothing that would motivate people to stay in the country. Everything is just slogans and lies and we haven't done anything either. We can do many things but we don't like giving notebooks and pens to children and providing jobs for people. Our people are dishonoured and insulted in other countries but we haven't done anything for them. In Baharak District, 2000 acres of land were allocated to returning refugees in the time of Karzai but the land remained as it was and there has been no investment on it. I don't think your [i.e. AHRRAO's] activities will solve anything either" (DRR, 2 March 2016, Taloqan).

A number of government departments, as well as the provincial councils interviewed, claim to have conducted discussions and met elders to discuss the risks of migration.

"The Provincial Council informs people about every event in the area according to the law. We have established a committee whose members should go to the districts and speak to Mullahs in mosques asking them to prevent migration by admonishing it in their sermons. This wasn't a law. We have provided a seminar in districts. It was implemented in Chah Ab, Namakab, Warsaj, Farkhar and Kalafgan Districts and tried to persuade people not to migrate. It had good effects" (Provincial Council, 2 March 2016, Taloqan).

Probably the most professional attempt to address the issue of migration was undertaken by the Department of Refugees and Repatriation (DRR) in Mazar-e Sharif:

"Our colleagues had a survey about those who returned to the country recently. They encouraged people to stay in the country. For example, we had a conference in the hall of Information and Culture Department with cooperation of IOM (International Organisation for Migration) on 22 March 2016. The participants were 50 mullahs and Maulawis and 50 university students. We informed them about the risks and dangers of illegal migration. They can inform others about it. However, its result is not clear yet" (DRR, 31 March 2016, Mazar-e Sharif). 
These interviews make it very clear that even though most government officials, civil society members and other influential individuals interviewed consider this wave of migration a problem for the country, there is no coordinated policy to counter it or even a systematic understanding of the scope and causes of the problem.

\section{Conclusions}

\section{Motivations of the population (pull \& push)}

From the perspective of an average person living in a town or city of North or NorthEast Afghanistan, there are several reasons to consider migrating to Europe (push factors). After years of economic growth and expansion, in the last two-three years growth has declined and poverty increased. Following the withdrawal of ISAF, security has also deteriorated dramatically throughout the country, including the North and North-East. The temporary fall of Kunduz City to the Taliban marked a low point in this respect.

In 2015 these negative developments, compelling people to migrate from Afghanistan, came together with a number of powerful factors attracting people to migrate to the EU (pull factors), and within the EU to Germany in particular, culminating in a massive wave of migrants entering the EU in the course of the year. Our interviews identified (a) peace, (b) a good economy including job opportunities, (c) a welcome culture in Germany and (d) a dramatic drop in the costs of migration as pulling (attracting) people to migrate to the EU.

While at first glance most of the identified push and pull factors appear to make sense, at closer glance they seem to be insufficient to explain the sudden and dramatic increase in Afghan migration beginning early 2015. Moreover, the combination of the above mentioned push and pull factors actually represents a riddle, which we will have to clarify.

First and foremost, while the push factors "deteriorating security" and "bad economy" are well-known reasons for flight and migration, they have been present for the last several years and their deterioration was gradual. As a result, these push factors are insufficient to explain the sudden wave of Afghan migrants reaching the $\mathrm{EU}$ in the mid-summer and early autumn of 2015. Two of the pull factors, peace and good economy in the EU on the one hand, and a welcome culture in Germany, on the other, can also be excluded as having triggered the 2015 migration using a similar logic. Peace and a good economy in the EU predates the migration wave, while the public manifestations of a welcome culture (statements of leading politicians and mass demonstrations), were only performed in late August and early September 2015 , when the wave of migrants has already reached the EU. 
To put it differently, the push factors, bad security and poor economy, explain a general and growing desire to flee from Afghanistan to more peaceful and prosperous countries. These factors do not explain, however, the unexpected wave of migrants that reached the EU mid to late summer 2015 and which, given the time required to prepare the journey and arrive in the EU, must have started early 2015. Similarly, the temporary fall of Kunduz very likely strengthened the desire among many Northern Afghans to leave the country, but it could only have accelerated the already massive wave of migration. The pull factors - peace and prosperity in the EU - explain why many Afghans chose the EU as their destination, but do not explain why the numbers of Afghan who decided to migrate to Europe suddenly increased so dramatically early 2015. In the same vein, the frequently cited German "welcome culture" can explain an acceleration of migration in early and mid-autumn 2015, but cannot have triggered the wave of migration that has its origins in early 2015. This leaves us with the pull factor - strong "drop in the monetary cost of migration" cited by a large number of interview partners as having triggered the dramatic increase in migration to the EU, as well as information shared over electronic communication and social media about migration routes and the modalities of reception in the EU.

A strong drop in the monetary costs of migration (understood as a reduction in smuggler fees and migrant travel expenses) is particularly puzzling, as under normal market conditions, an increase in demand, i.e. people wanting to migrate - as suggested by the push factors "bad security" and "poor economy" - should lead to an increase in prices. This effect should be at least temporary until the increased demand is matched by an increased supply, as smugglers open up new routes and establish new corrupt relations with officials along the migration route. What actually happened in North and North-East Afghanistan is the exact opposite of these expectations: prices dropped. Why this might be so and what actually explains the 2015 wave of migration, will be discussed in the next section.

\section{Smuggler fees and modes of migration}

In order to investigate the riddle of a reduction in smuggler fees coinciding with a heightened push to migrate, we interviewed Mazar-e Sharif-based smugglers and our own acquaintances who have migrated to Europe. We compiled the information gained from these interviews together with open source data on registered migrants and key developments in Afghanistan, as well as major events along the migration route, in a timeline (see Figure 3).

The timeline shows that the wave of Afghan migrants entering Europe through Greece gradually gathered pace over the spring and early summer months, culminating in October and November 2015. Subsequently, the numbers began to drop until they were reduced to a trickle following the signing of the EU-Turkey 
agreement on 18 March 2016 (coming into effect two days after signing on 20 March 2016). Importantly, the wave of Afghan migrants was preceded by a dramatic drop in the costs of illegal migration to Europe towards the end of 2014 and beginning of 2015. For the years prior to 2015, prices for a trip to Europe were relatively stable ranging from $\$ 14-17,000$ per person. In early 2015 , these costs dropped to around $\$ 2,500-3,000$ (interviews with human smugglers on 15 May 2016). ${ }^{14}$ These figures represent a lowering of prices by $82 \%-85 \%$ as compared to the high of $\$ 17,000$. Considering the time needed for the drop in prices to become widely registered among the population, the preparations needed to establish contacts and gather the money (borrow money or sell property) and, lastly, the actual time needed to reach Greece, the drop in prices in early 2015 might well have been the key event triggering the Afghan migrant wave.

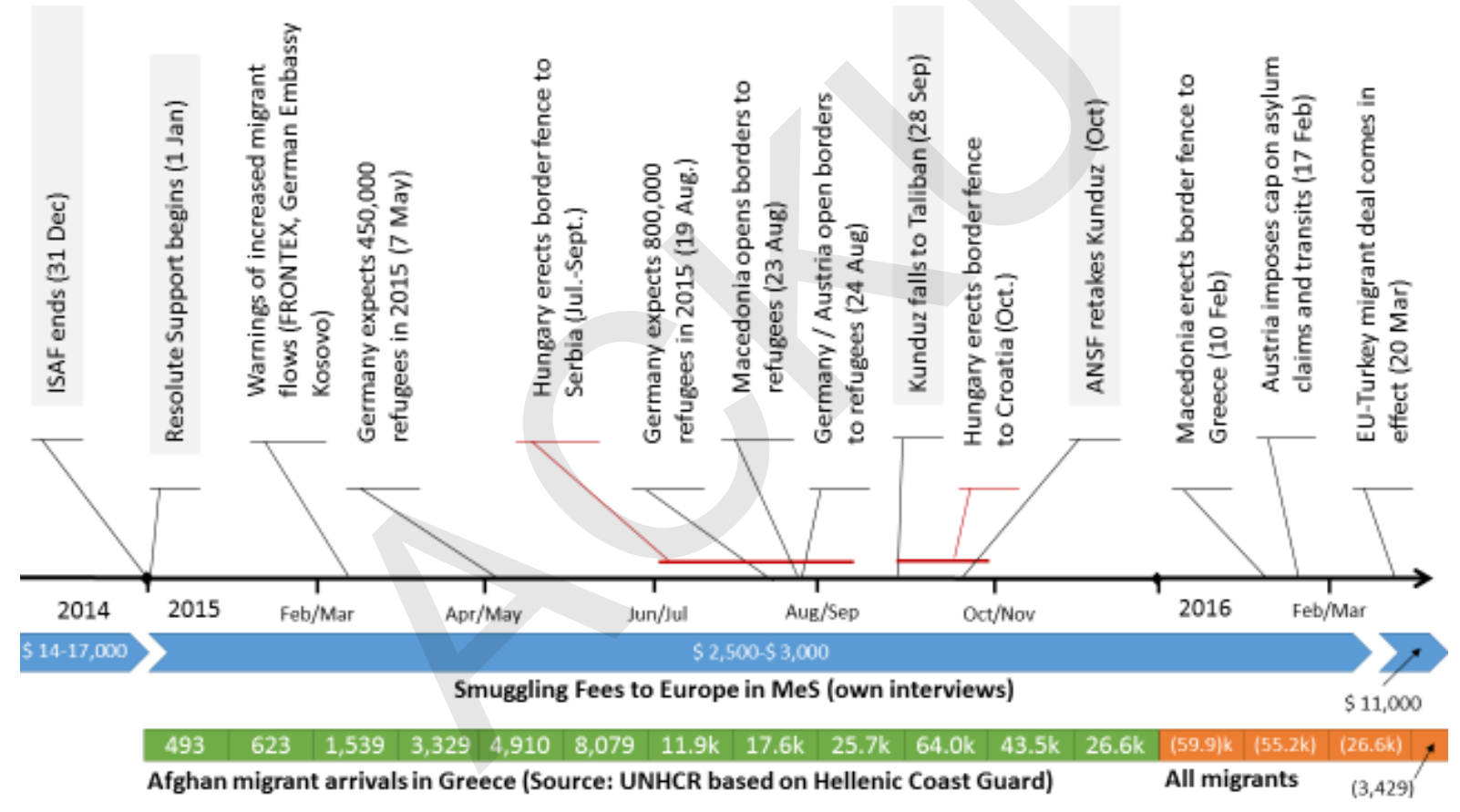

Figure 3: Timeline of the $\mathbf{2 0 1 5}$ migrant crisis from an Afghan perspective

\footnotetext{
${ }^{14}$ Part 2 of AAN's report on Afghan migration to Europe mentions prices between $\$ 1,500$ and $\$ 8,000$ to reach Europe. These prices, too, are well below the prices quoted for the years prior to 2015 , i.e. $\$ 14-17,000$.
} 


\section{Case Example}

Migration of an Afghan family: an Afghan acquaintance from Mazar-e Sharif contemplated throughout the summer of 2015 illegally migrating with his family to Germany. He left Afghanistan at the end of October 2015, arriving in Istanbul on 16 November. About 10 days later he and his family boarded a boat bound to a Greek island and arrived there safely on 26 November 2015. The family arrived midDecember in Germany. Including the preparations, the trip lasted approximately four to five months.

The key question thus is, what explains the unexpected drop in prices late 2014 and early 2015? Our interviews with human smugglers in Mazar-e Sharif revealed important changes in how the market operated and how would-be migrants travelled along the migration route prior to 2015 and in 2015 and early 2016. Originally, prior to 2015, smuggling and the modes of travel along the migration routes were expensive (around $\$ 14-17,000$ ) and the offer of smugglers was highly structured and regulated. In order to reduce the risk of betrayal by the smuggler, migrant payments were made to a trusted third party who would only release the agreed fee to the smuggler following the arrival of the migrant at his or her agreed destination. Moreover, the people smuggler guaranteed the arrival of his client (the would-be migrant) at an agreed destination, i.e. if the migrant was apprehended and deported, the smuggler would be responsible to undertake a new attempt to bring the client to his or her destination. This system appears to have been very widespread in Afghanistan (see e.g. CNN, 16 October 2015) ${ }^{15}$.

According to our interviews with Mazar-e Sharif-based smugglers, this system became partly obsolete in early 2015. People started to understand that they could pass the borders all the way up to the Turkish coast without the support of smugglers and, consequently, there was no need to pay for smuggling. This knowledge, and knowledge of the migration route to take, was passed on via mobile phone and electronic communication as well as via social media and quickly changed the business model of smugglers. Thus from January 2015 until about February 2016 the mode of migration changed. Instead of "booking" guaranteed departure-todestination transport, an increasing number of migrants felt sufficiently confident to undertake the trip individually, only paying smugglers at critical points (mostly at borders). This shift from smuggler-facilitated migration to a mostly unprotected individual travel mode was also confirmed to us by interview partners of the household level survey:

\footnotetext{
${ }^{15}$ http://edition.cnn.com/2015/10/16/asia/afghanistan-kabul-people-smugglers-robertson/
} 
"The costs of migrating to Europe has decreased as compared to several years ago. People paid money for smugglers to go to Europe in the past. Now people do not need smugglers anymore. They learned how to migrate to Europe. If they can reach Turkey, they will not have any problems anymore" (10 Feb 2016, Mazar-e Sharif).

The costs associated with this independent mode of migration were described to us by smugglers as follows: migrants would pay smugglers to get to Iran for about $\$ 600$. After crossing the Afghan-Iranian border, migrants would travel on their own to the Iranian border with Turkey and would then turn to smugglers there. Crossing the Iranian-Turkish border would cost $\$ 500-700$. From there they travelled apparently without serious harassment by authorities, to the Turkish coast where they negotiated their sea fare ranging from $\$ 300$ to approximately $\$ 2,000$, depending on the mode of maritime transport. Upon arrival on the Greek islands, migrants would register with UNHCR and eventually continue with their travel along the Balkan route. The smugglers we interviewed explained that the police in Turkey and Greece would help migrants along the route. Effectively, as the smugglers emphasised, Turkey and Greece did not seriously control their borders in 2015 and traveling to and crossing Iran was, and is, easy.

This supportive (or at least indifferent) attitude of authorities is very likely a key reason why migrants could switch from travelling under the protection of smugglers to undertaking the overland travel in the key transit countries Turkey and Greece on their own. In its turn, the cost savings associated with the shift to the much cheaper mode of self-organised migration, appear to have played a key role in triggering the massive wave of migration from Afghanistan which reached the EU in the summer and fall of 2015.

This mode of self-organised migration from Afghanistan to Greece appears to have been the predominant form of migration from January 2015 until about February 2016. Right now, migration costs are once again climbing and are currently around $\$ 11,000$ (as of 15 May 2016). Importantly, the "old" business model of smugglers charging higher prices, but also guaranteeing arrival at destination, once again dominates the offer. The smuggling business is back to normal.

This shift back to higher prices and the "old" offer of guaranteed arrival coincides with the gradual closure of the Balkan Route, and, crucially, with the EU-Turkey migrant agreement, coming into effect on 20 March 2016. That the route through Turkey is now mostly closed is also evident through the migration route the Mazar-e Sharif-based smugglers we interviewed now offer: the route leads through Russia and enters the EU in Bulgaria. It thus seems that the 2015 migrant wave was triggered by the increased ease of travelling through Turkey leading to a drop in prices, and was stopped by the EU-Turkey agreement leading to a more rigorous control of migration routes. 